\title{
Beyond venture capital: an exploratory study of the finance-innovation-policy nexus in cleantech
}

\section{Michael Migendt, ${ }^{1}$ Friedemann Polzin, ${ }^{2,3,4}$ Florian Schock, ${ }^{5}$ Florian A. Täube $^{6,7, *}$ and Paschen von Flotow ${ }^{8}$}

1Department of Innovation Management and Entrepreneurship, EBS University Rheingaustraße 1, Oestrich-Winkel 65375, Germany. e-mail: michael@migendt.net, ${ }^{2}$ Department of Innovation Management and Entrepreneurship, EBS University Rheingaustraße 1, 0estrich-Winkel 65375, Germany. e-mail: f.polzi n@uu.nl, ${ }^{3}$ Sustainable Business Institute (SBI), Zehnthofstr. 1, Oestrich-Winkel 65375, Germany. e-mail: f.polzin@uu.nl, ${ }^{4}$ Chair of Strategy, Organization and Entrepreneurship and Sustainable Finance Lab (SFL), Utrecht University School of Economics (U.S.E.), Kriekenpitplein 21-22, Utrecht 3584 EC, The Netherlands, E-mail: f.polzin@uu.nl, ${ }^{5}$ Department of Innovation Management and Entrepreneurship, EBS University Rheingaustraße 1, 0estrich-Winkel 65375, Germany. e-mail: florian.schock@web.de, ${ }^{6}$ Professorship of International Business and Entrepreneurship. Department of International Business, European Management School (EMS), Rheinstrasse 4N, 55116 Mainz, Germany. e-mail: f.taeube@ems.de, ${ }^{7}$ International Centre for Innovation, Technology and Education Studies (iCite), Solvay Brussels School of Economics and Management, Université libre de Bruxelles, Avenue F.D. Roosevelt 42, Brussels 1050, Belgium. e-mail: ftaube@ulb.ac.be and ${ }^{8}$ Sustainable Business Institute (SBI), Zehnthofstr. 1, OestrichWinkel 65375, Germany. e-mail: flotow@sbi21.de

*Main author for correspondence.

\section{Abstract}

In recent years, scholarly interest in financing for innovation has grown, particularly for mitigating climate change. However, extant literature has neglected the interaction of actors along the equity financing value chain, and the indirect effects of innovation and financial policy on the supply and demand of private equity (PE) and venture capital (VC). In this article, we emphasize the importance of these understudied aspects through a comparative case study of equity finance for cleantech in the United States and Germany. We find that systemic interdependencies between institutional investors, VC/PE and policy makers influence the conditions for innovation-the "finance-innovation-policy nexus." Adverse effects of policies affecting financial markets, in particular institutional investors, have to be taken into account to effectively mobilize private investments for (cleantech) innovation.

JEL classification: G24, G28, 031, 032, 042, 048

\section{Introduction}

In recent years, scholarly interest in financing for innovation has grown, particularly for mitigating climate change (Mowery et al., 2010; Arora et al., 2014; Mingo and Khanna, 2014). This arises from a recognition that to transition 
to a more sustainable economy, at least part of the necessary innovations will come from entrepreneurial ventures rather than incumbent corporations (Garud and Karnøe, 2003; Sine and David, 2003; Dean and McMullen, 2007; Hockerts and Wüstenhagen, 2010; Mrkajic et al., 2016). The single biggest problem for these entrepreneurial firms is access to finance (Lerner, 2002a; Schneider and Veugelers, 2010; Mina et al., 2013; Stucki, 2014). Although the share of cleantech Venture Capital (VC) deals as a percentage of all deals rose from 1\% to 10\% between 1996 and 2010 (Cumming et al., 2016), investments into key enabling technologies (cleantech, ${ }^{1}$ nanotech, and biotech) have only recently seen a slight recovery (McCrone, 2015). This, even in the context of recent changes in monetary policy leading to low interest rates and heavy injections of liquidity into financial markets (Belke, 2013).

This low cleantech investment environment follows the financial crisis of 2008 and has been particularly prevalent in early-stage VC where financing has almost disappeared (see Figure 1). Moreover, early-stage investors have

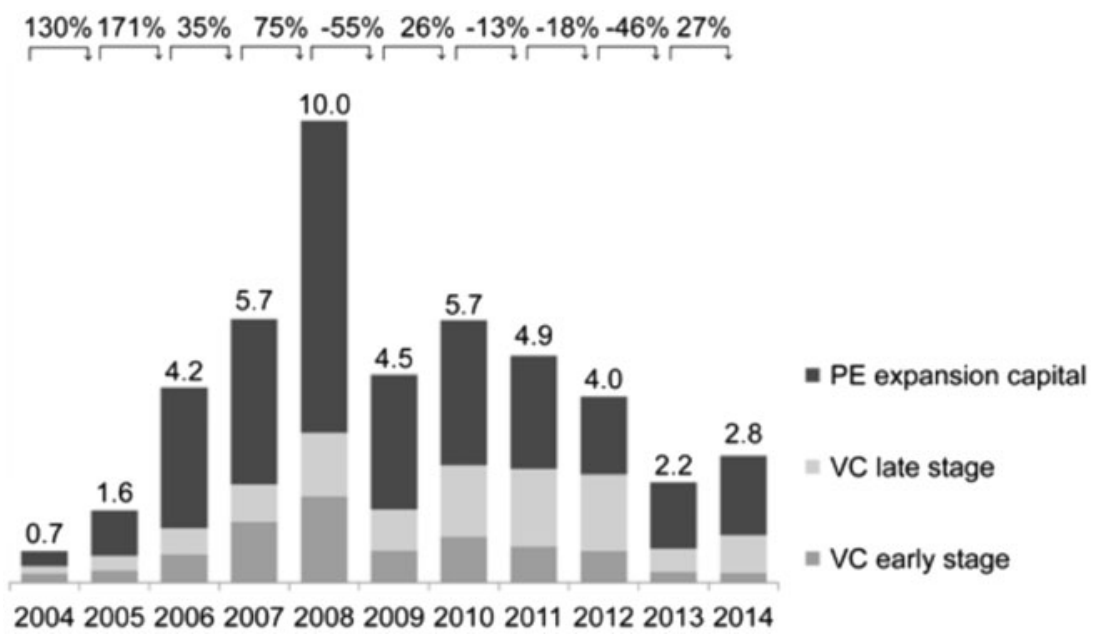

Figure 1. Global VC/PE investment in cleantech by stage in USD bn.

Source: McCrone (2015).

shifted their focal investment activities to later stages (Block and Sandner, 2009; Ning et al., 2015).

Cleantech ventures exhibit specific characteristics that limit their access to capital. These include greater technological uncertainty, higher policy risk, asset heaviness, slower scalability, and corresponding long payback periods (Foxon and Pearson, 2008; Hockerts and Wüstenhagen, 2010; Hargadon and Kenney, 2012; Petkova et al., 2014; Polzin et al., 2016). Policy intervention is justified to address these characteristics, unlike in other high-tech industries. Current literature demonstrates that cleantech industries and investments can be stimulated by a number of technology-push and demand-oriented market-pull mechanisms (Haley and Schuler, 2011; Veugelers, 2012; Olmos et al., 2012; Polzin et al., 2015).

Despite the importance of innovation by entrepreneurial ventures in the transition to sustainable economies, there is little research that addresses the early-stage financial value chain for equity financing (in cleantech), let alone the impact of policy on this (for an overview, see Perez, 2002; O'Sullivan, 2005; Hirsch-Kreinsen, 2011). Most existing literature (both for general innovation and cleantech) is limited to an analysis of the VC-entrepreneur relationship (Kenney, 2011b; Dimov et al., 2012; Petkova et al., 2014) or the policy-VC relationship (Kortum and Lerner, 2000; Bottazzi and Da Rin, 2002; Lerner, 2009; Hargadon and Kenney, 2012; Lerner and Tåg, 2013). Yet, this ignores two important interactions in the finance-innovation-policy nexus: first, the source of funds that propels private equity (PE)/VC—institutional investors; second, policies that affect their role in the financial value chain. Our research seeks

1 Technologies that focus on sustainability, mitigation, and adaptation to climate change, or reduction of natural resources. For example, solar or wind energy technologies, electric cars, energy efficiency technologies, and other smart resource reduction approaches (Pernick and Wilder, 2007; 0'Rourke, 2009; Caprotti, 2012). 
to develop insight into these important interactions, with our research question as follows: How do innovation and financial policy influence the supply and demand of equity finance along the financial value chain?

In this article, we investigate these hitherto neglected interactions in the finance-innovation-policy nexus and how these affect the equity finance value chain for cleantech by comparing the United States and Germany. We contribute to the literature by extending our model beyond the VC-innovator relationship to include the institutional investor, and we identify indirect effects that might follow policy measures due to this expanded view of the equity finance value chain. While innovation policy might try to foster cleantech start-up financing through measures aimed at VC and PE, regulatory requirements in earlier stages of the value chain could counteract the intended effect. We hypothesize that VC/PE investors refrain from risky investments into early-stage cleantech ventures as a result of regulatory tightening of their own sources, namely, institutional investors.

\section{Theoretical background}

\subsection{Role of the finance ecosystem for innovation}

The main financiers of innovation ventures are (1) VC with early-stage and growth equity characterized by a high risk/return profile (Kortum and Lerner, 2000; Bottazzi and Da Rin, 2002; Oakey, 2003; Dimov et al., 2012) and (2) PE with late-stage, expansion and turnaround equity characterized by a lower risk/return profile (Wright and Robbie, 1998; Wright et al., 2009; Lerner et al., 2011; Schock, 2014). VC and PE source their funds in turn from institutional investors such as investment and pension funds, banks and insurance companies, and strategic VC/PE investors seeking long-term, stable returns (Brossard et al., 2013; OECD, 2013). Institutional investors, VC/PE firms, and innovators themselves comprise the equity finance value chain for innovation which provides the baseline for

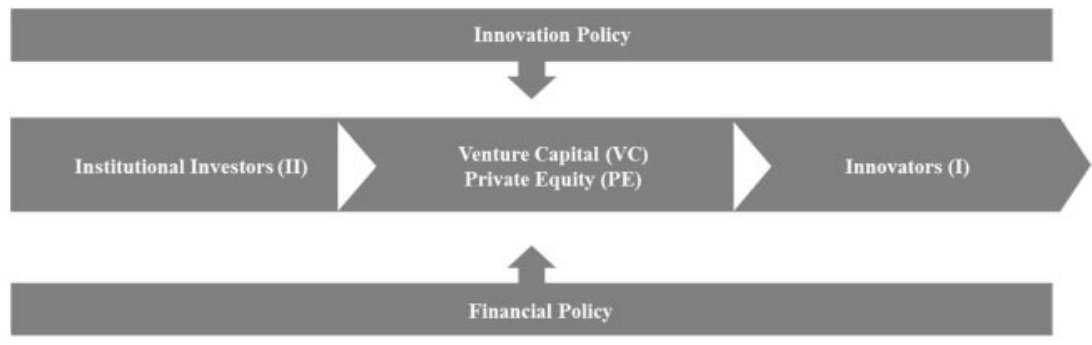

Figure 2. Theoretical framework.

our theoretical model (see Figure 2).

Most of the literature on financing innovation focuses on the VC-innovation/innovator relationship. At an aggregate level, extant research finds a positive impact of VC/PE on technological change, innovation, and economic growth (Kortum and Lerner, 2000; Bottazzi and Da Rin, 2002; Samila and Sorenson, 2010). At a micro-level, scholars highlighted the positive impact of early-stage investments in subsequent survival, firm growth, etc. (Davila et al., 2003; Fitza et al., 2009; Colombo and Grilli, 2010; Huang and Knight, 2015).

A similar picture can be drawn from the literature addressing alternative investments in cleantech industries. Thus far, scholars have looked at the emergence of these investors and their contribution to low-carbon innovation including how they address some of the unique characteristics of cleantech such as high technology risk (Randjelovic et al., 2003; Moore and Wüstenhagen, 2004; Ghosh and Nanda, 2010; Marcus et al., 2013). Cumming et al. (2016) provide an overview about the drivers of cleantech investments worldwide such as oil prices, legal, and institutional variables. Earlier work points out some limitations of the VC business model in addressing characteristics such as slow scalability, limited fund sizes, and missing exit opportunities reputation risk (Kenney, 2011b; Nanda et al., 2014; Petkova et al., 2014; Kenney and Hargadon, 2014; Bocken, 2015; Mrkajic et al., 2016) which can lead to a shortage of early-stage risk capital for these types of ventures (Demirel and Parris, 2015).

Beyond this, there is limited coverage of other parts of the equity finance value chain, with a few examples describing the evolution and functioning of a (regional) financial ecosystem for innovation in general (Oakey, 2003; 
Avnimelech and Teubal, 2006; Kenney, 2011b; Wonglimpiyarat, 2011; Revest and Sapio, 2013; Grilli and Murtinu, 2014). Critical to the development of this field is a greater understanding of how the three components of the equity finance value chain interact, particularly bringing in the perspective of the institutional investor (Brossard et al., 2013).

\subsection{Public policy influence on the finance-innovation relationship}

Table 1. Innovation and financial policy influencing innovation

\begin{tabular}{|c|c|c|}
\hline Type of policy & Examples & Sources \\
\hline $\begin{array}{l}\text { Innovation policy } \\
\text { (market pull) }\end{array}$ & $\begin{array}{l}\text { Cash rebates, direct investments, loan guaran- } \\
\text { tees, subsidies, tax incentives, feed-in tariffs }\end{array}$ & $\begin{array}{c}\text { Bürer and Wüstenhagen, 2009; Haley and Schuler, 2011; } \\
\text { Hoppmann et al., 2013; Peters et al., } 2012\end{array}$ \\
\hline $\begin{array}{l}\text { Innovation policy } \\
\text { (technology } \\
\text { push) }\end{array}$ & R\&D support, subsidies, tax credits & $\begin{array}{l}\text { Bürer and Wüstenhagen, 2009; Olmos et al., 2012; } \\
\text { Wüstenhagen and Bilharz, } 2006\end{array}$ \\
\hline $\begin{array}{l}\text { Financial policy } \\
\text { (framework } \\
\text { conditions for } \\
\text { VC/PE) }\end{array}$ & $\begin{array}{l}\text { Tax policy, capital market development, bank- } \\
\text { ruptcy, legislation, securities legislation, labor } \\
\text { market regulation }\end{array}$ & $\begin{array}{l}\text { Bottazzi and Da Rin, 2002; Cumming, 2011; Da Rin et al., } \\
\text { 2006; Lerner, 2002; Lerner, 2010; Lerner and Tåg, 2013; } \\
\text { Lerner, } 1998\end{array}$ \\
\hline $\begin{array}{l}\text { Financial policy } \\
\text { (regulation) }\end{array}$ & $\begin{array}{l}\text { Investment mandate regulation, risk assessment, } \\
\text { capital market rules }\end{array}$ & Not discussed in the relation to (cleantech) innovation \\
\hline
\end{tabular}

To mobilize PE funds through the equity finance value chain, policy makers deploy a set of instruments targeting innovators spanning regulation, economic, and voluntary mechanisms (Mathews et al., 2010; Flanagan et al., 2011; Veugelers, 2012; Borrás and Edquist, 2013; Magro and Wilson, 2013; Rogge and Reichardt, 2016) (see Table 1).

There is a stream of literature focused on formal institutions (including policy) and incentives that are conducive to equity finance for innovation. First, much research compares European and US VC markets (Lerner, 2002b; Avnimelech et al., 2010; Kenney, 2011a; Lerner and Tåg, 2013) to assess the role the structure of the financial system (debt vs equity) has on private investment in entrepreneurial ventures. Active stock market and VC investment are mutually dependent institutions that allow for initial public offering (IPO) as preferred exit channel. In a bankcentered system, by contrast, a conservative attitude to innovation and lending prevails (Black and Gilson, 1998; Lerner and Tåg, 2013). The authors conclude that strengthening capital market development to allow for better exit opportunities can mobilize VC/PE investments (Bottazzi and Da Rin, 2002; Da Rin et al., 2006; Da Rin et al., 2006). Second, the structure of taxes is an important policy area affecting VC/PE investments (Lerner, 2010). Keuschnigg and Nielsen (2003) found that capital gains taxation strengthens incentives for VC/PE while weakening the incentives for entrepreneurs, while a wage tax has the opposite effect (Bottazzi and Da Rin, 2002; Da Rin et al., 2006). Third, entrepreneur-friendly bankruptcy and securities legislation (i.e. the possibility to sell parts of the invested fund) lead to an increase in VC/PE activity (Lerner, 1998; Cumming, 2011).

Fourth, there is ambiguous evidence regarding public VC (co-)investments as a means to encourage private contributions. Lerner (2002a, 2009) highlights possible certification and knowledge spillovers by VC programs. Whereas a priori co-investments and subsidies reduces the risk of the private investor, crowding out of private VC/PE activities might occur when government funds do not increase the overall supply of capital nor the exit possibilities (Lerner, 2002b; Cumming, 2011).

Evidence from Canada also implies that too much available fund capital can lead to failures or overinvestment and underperforming funds (Cumming, 2011). From the United States, evidence suggests that policy makers need to understand the entrepreneurial and investment processes, assess prior funding for research and development $(R \& D)$ activities, and know criteria being used by investors (e.g. flexibility, customer orientation) when designing supportive VC environments (Lerner, 2002b; Lerner, 2010). Similarly, Avnimelech and coauthors (Avnimelech and Teubal, 2006, 2008; Avnimelech et al., 2010) argue that policy interventions should be based on a strategic long-term commitment and follow industry lifecycles and regional contexts to effectively mobilize private investments through $\mathrm{VC/}$ 
PE. These range from competitive and cooperative R\&D grants to increase learning, government co-investments, and public-private partnerships, incrementally involving the private sector.

Finally, scholars have taken a more holistic approach to the VC-Policy relationship. For example, Li and Zahra (2012) show the positive influence of formal institutions using an index that covers government effectiveness, quality of regulatory policies (including the ones mentioned above), and political stability on VC/PE investments. Lerner and Tåg (2013) compared the VC financing systems of the United States and Sweden, highlighting key institutions such as the legal environment, financial market development, taxation, labor market regulations, and public R\&D spending as most relevant for the creation of active VC markets. One of their findings relates a thriving VC industry to exit opportunities in developed financial markets. They also found a positive influence of deregulation, e.g. allowing pension funds to invest in VC (Gompers and Lerner, 2001). On the other hand, tightening regulation has not been studied as an influencing factor for PE investments (Lerner and Tåg, 2013).

In a second stream of literature focused on the cleantech sector, public policy is considered a main driver for market development, as it adjusts institutions and supports specific sectors by using technology-push and demand-pull mechanisms (Tsoutsos and Stamboulis, 2005; Olmos et al., 2012; Hoppmann et al., 2013; Criscuolo and Menon, 2015; Polzin et al., 2015). Olmos et al. (2012) discuss policy measures and financing instruments to induce cleantech innovation, highlighting subsidies, loans, equity investments, and tax credits as suitable. Hoppmann et al. (2013) argue that deployment policies leads to a shift of investments in companies to pursue more mature technological trajectories, limiting their investments in novel explorations ("investor effect”) which is valued by VC investors (Bürer and Wüstenhagen, 2009). Demirel and colleagues (Demirel and Kesidou, 2011; Kesidou and Demirel, 2012; Demirel and Parris, 2015) assert that environmental regulations drive eco-innovations and corresponding investments. Finally Veugelers (2012) and Criscuolo and Menon (2015) find that deployment measures focusing on the long term are conducive to innovation and VC investments in cleantech. This corresponds with research into policy implementation which highlights regulatory uncertainty and policy risk as major barriers (Marcus et al., 2011; Lüthi and Wüstenhagen, 2012).

Today, there is no comprehensive view on the interdependencies between policy makers, financiers (the full finance value chain), and cleantech entrepreneurs. We bridge these two streams of literature to analyze interactions between relevant actors in the financial value chain (in the cleantech sphere). More specifically, we address a lack of knowledge about the impact of specific industry-related innovation policies and general financial regulation policies on equity investment and cleantech industry emergence (Lerner, 2002b; Avnimelech and Teubal, 2006; Avnimelech and Teubal, 2008; Cumming, 2011). From a systemic perspective, innovation in cleantech is influenced not only by innovation-oriented policies but also by financial policies affecting VC/PE sources of finance (see also the discussion of systemic problems by Edquist, 2011; and Weber and Rohracher, 2012). Covering only parts of what we call "finance value chain" or neglecting interaction within the finance-innovation-policy nexus can lead to distorted results regarding effects on innovation financing. In this article, we investigate direct and indirect effects of financial policy and innovation-oriented policies in cleantech in a cross-country comparison.

\section{Method and data}

To refine extant theory by analyzing the finance-innovation-policy nexus in cleantech, we use a qualitative, case study-based research approach (Eisenhardt, 1989; Flyvbjerg, 2006; Yin, 2009). Our research covers the cleantech area, especially in the field of innovative companies funded by VC/PE capital or requiring external equity capital. Although investment data are provided (aggregated and at deal level) little is known about the mechanisms and influencing factors behind the financing decisions of investors and the unfulfilled financing needs of innovators along the financial value chain. Through 64 interviews, we can draw on the experiences of the actors in the industry and combine the perspectives of different actors to enrich theory (similar methodologies have been applied in Jain and George, 2007; Aversa et al., 2015). We chose Germany and the United States to illustrate the effects of different equity market structures on innovation activities in two relevant cleantech markets (Seawright and Gerring, 2008). 


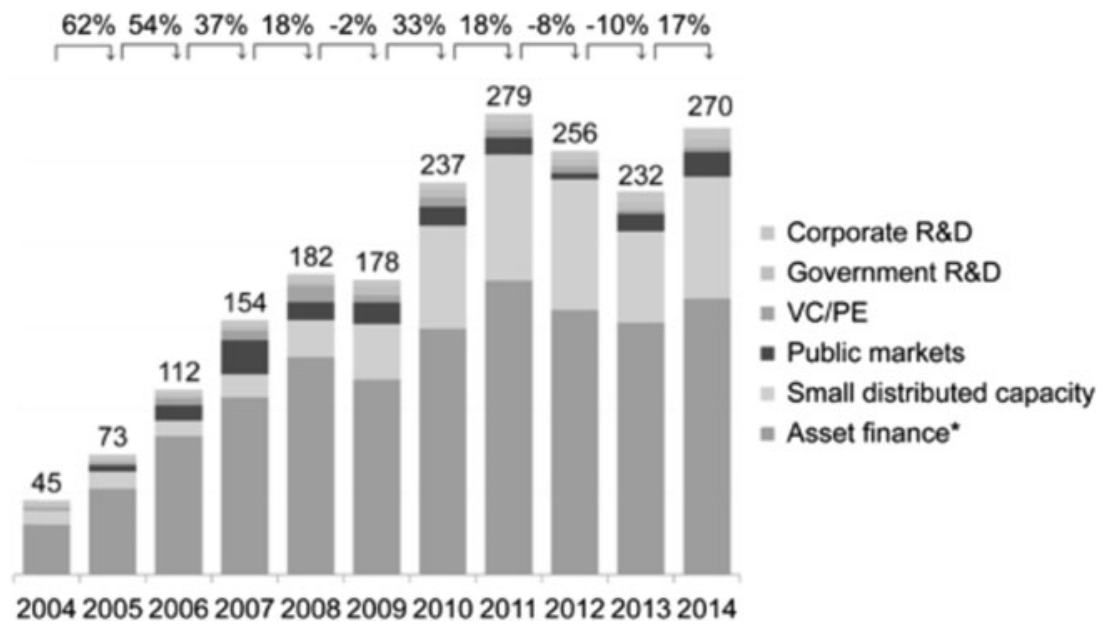

Figure 3. Global new investment in cleantech in USD bn.

Source: McCrone (2015)

\subsection{Research context}

The cleantech sector has been growing rapidly which can be seen from the financial flows into the different asset classes (Figure 3). ${ }^{2}$ Starting from the early 2000s, cleantech experienced rapid growth until the financial crisis in 2008. This slowed down the pace of development, recovering shortly thereafter with a continuing growth, notably in asset finance and new electricity-generating capacity (Ettenhuber, 2013; PwC Moneytree, 2014).

The financial crisis spurred restrictive financial policies and a series of recovery policies for cleantech industry in the United States and Europe alike. On the financial side, these measures include Basel III, ${ }^{3}$ Solvency II, ${ }^{4}$ the DoddFrank Act, ${ }^{5}$ and the Volcker rule. ${ }^{6}$ On the industrial side, there was an unprecedented surge of government R\&D and grant capital commitments to the sector. This coincided with shrinking bank-lending and VC/PE activities throughout the United States, Europe, and Germany despite expansive monetary policy (see Figure 3). This highly supportive public environment for cleantech innovation consisted of measures such as cash rebates, direct investments, loan guarantee programs (LGPs), feed-in tariffs, and R\&D support. Even though the cleantech sector, especially the deployment of new technologies, was supported by policy, investment activity in the United States and

2 Here we use the investments in clean/renewable energy technologies as a proxy for investments for cleantech in general. BNEF provides the most comprehensive database concerning different asset classes for cleantech (i.e. Asset finance, VC/PE, M\&A, Public Equity, Corporate debt, etc.). Similar trends can be observed in broader databases such as Thomson Reuters (PwC Moneytree, 2014; PwC Moneytree, 2015).

3 Basel III is a comprehensive set of reform measures to strengthen the regulation, supervision, and risk management of banks. It includes several pillars which increase capital and liquidity requirements and demand more risk discipline (Bank for International Settlements, 2010).

4 The Solvency I and II directives represent regulations covering the amount of equity capital that insurance companies are required to hold to reduce the risk of insolvency. Depending on the categorization in the Solvency risk model, investments by insurance companies are required to be backed with more or less equity capital (European Commission, 2014).

5 The Dodd-Frank Wall Street Reform and Consumer Protection Act, signed in July 2010, is a major financial reform to promote the financial stability of the United States by improving accountability and transparency in the financial system. The Act established new government agencies and introduced several measures to increase stability and oversight (111th Congress of the United States of America, 2010).

6 The initial version of the Volcker Rule of the Dodd Frank Act prohibited banks to engage in proprietary trading and to invest in alternative asset classes such as hedge funds and private equity funds. In the final version, the ban to invest in hedge funds and private equity funds was abandoned whereas the ban on proprietary trading was implemented (111th Congress of the United States of America, 2010). 


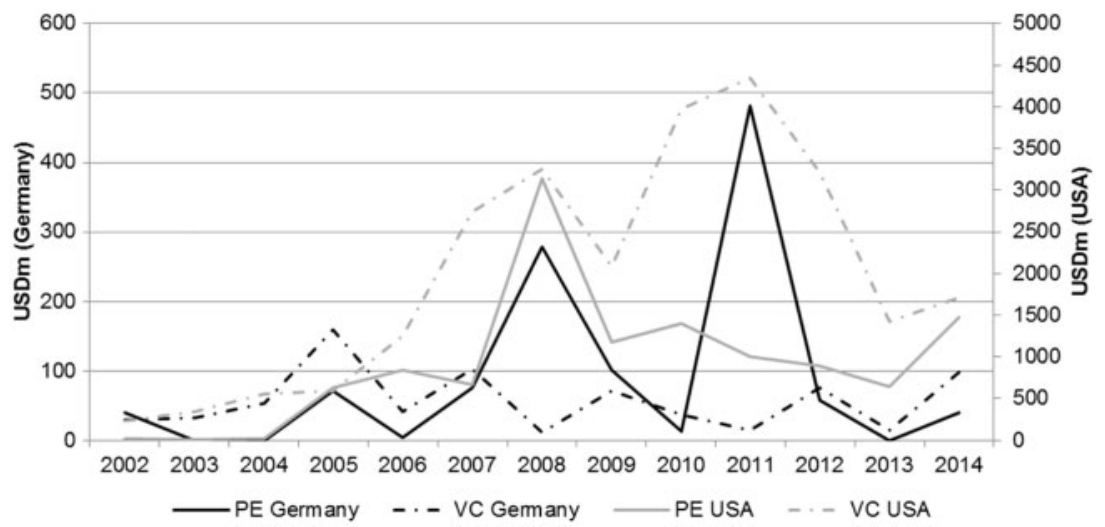

Figure 4. New investment in cleantech (USA and GER) in USD bn.

Source: BNEF (2015)

Germany declined over the years as can be observed (see Figure 4). With regard to VC investments, a slight recovery on a lower level is visible for the United States while investments in Germany could return to the level of 2005-2007. In 2014 the graphs show a steep recovery for PE investments in the United States, whereas Germany saw a weaker recovery.

These observed investments provide the context of our analysis of the perceptions of institutional investors, VC/ PE investors, policy makers, and innovators. Our analysis looks at interactions between actors in the policy-financeinnovator nexus, noting potential influences such as technology-specific factors, regulatory factors, or the financial crisis and corresponding measures.

\subsection{Data collection}

Based on our initial theoretical framework (see Figure 2) and participation in industry trade fairs, conferences, and conversations with more than 80 industry experts, we approached suitable interview partners (Flyvbjerg, 2006). In addition to the entrepreneurs/innovators in cleantech firms active in different industry subsectors, VC/PE investors, and policy makers, we also included institutional investors to complement previous analyses (Eisenhardt, 1989). These institutional investors act as limited partners for VC and PE funds but also invest directly into cleantech or as co-investors. We applied a mixture of criterion sampling, purposeful sampling, and extreme sampling to schedule a first round of interviews in the United States and in Germany. For a second interview round, we shifted to snowball sampling, asking our interview subjects to identify key contacts who would be a valuable addition to our initial sample (Bewley, 2002).

We primarily gathered qualitative data through semi-structured, open-ended interviews that lasted on average 55 min. ${ }^{7}$ These interviews collected perceptions of the cleantech finance-innovation-policy nexus from the market participants. The interviews were led by researchers with significant industry experience, who prepared the interviews through analyses of additional data, e.g. publicly available data and existing databases such as Bloomberg New Energy Finance $(B N E F)^{8}$ for specific investment deals and subsidy data and LexisNexis for newspaper articles and archival data on relevant policy measures (see section 2). Through the use of multiple sources of data, we were able to support the depth of the interviews and gather suitable narratives to validate our interpretations (Eisenhardt, 1989).

We were interested mainly in subsectors in cleantech for which VC or PE financing was not intuitive (e.g. solar technology, advanced transportation, biomass), as it usually involves high-technology risk (Haley and Schuler, 2011; Hargadon and Kenney, 2012; Schock, 2014). In addition, we strove to include extreme cases, i.e. cleantech firms that

7 A sample interview guide can be found in Table A4 (appendix).

8 BNEF includes deal-level data on investments and subsidies for most interviewed company, company investor, or VC/PE investment firm. 
Table 2. Overview of Interviews in the United States and Germany

\begin{tabular}{lcc}
\hline Region/ & United States & Germany \\
Interview partner category & 12 & 5 \\
\hline Cleantech companies & 11 & 4 \\
Venture capital & 5 & 6 \\
Private equity & 4 & 4 \\
Institutional investors & 9 & 43 \\
Policy makers/executives & 41 & 23 \\
Total &
\end{tabular}

either were particularly successful or were not successful in securing PE capital. Our sample includes both PE firms that did and did not allocate capital to the cleantech sector.

At the point when the interviews did not yield significant new insights, we had reached an appropriate level of saturation and thus concluded the field work (Glaser and Strauss, 1967; Francis et al., 2010). We conducted 64 interviews with executives in the cleantech sector, partners in VC firms, partners in later-stage PE firms, institutional investors, policy makers, and other stakeholders (41 in the United States and 23 in Germany-see Table 2). A detailed list of interview participants can be found in the appendix (Table A3).

\subsection{Data analysis and coding scheme}

For the purpose of structuring our analysis, we applied a theory-refinement approach (Creswell, 2003; Thomas, 2006). We went from personalized accounts with rich information to accounts that were more aggregated, abstract, and analytical as well as embedded in our theoretical framework (Figure 2). This iterative process involved going back and forth between the raw interview data and the theoretical framework (Corbin and Strauss, 1994; Huberman and Miles, 2002). For instance, after initial conversations with industry experts, we concluded that the asset alloca-

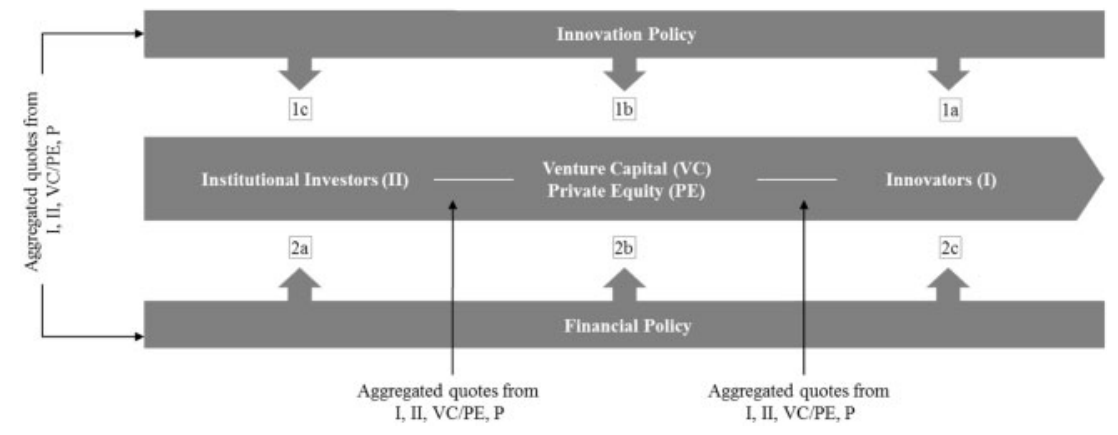

Figure 5. Coding process.

tion by private institutional investors was key to a thriving environment of the VC/PE sector prompting us to include these in our research.

In our initial data analysis, we focused on the perceptions of the interrelations between the major actors within the finance-innovation-policy nexus as our main categories for structuring and processing the incoming data. The established coding scheme portrays the interrelations between the actors: Policy-Institutional Investors, Policy-VC/PE, Policy-Innovators, Institutional Investors-VC/PE, PE/VC-Innovators, Institutional Investors-Innovators (see Figure 5). The coding process resulted in 625 individual quotes. Based on these relationships we could explore the direct and indirect consequences of innovation policy and financial regulation.

We investigated the relationships among the primary actors of the finance-innovation-policy nexus, specifically emphasizing previously unstudied relationships with institutional investors and contrasting Germany and the United 


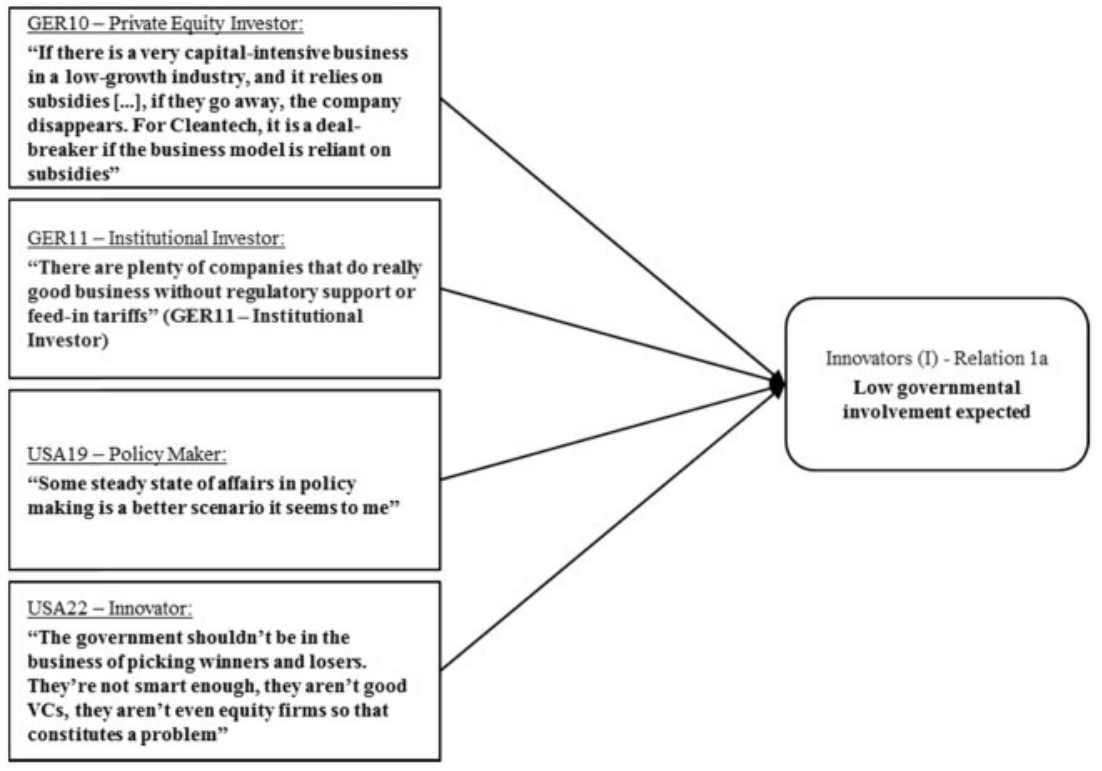

Figure 6. Example of coding process.

States. Within the actor-driven coding scheme, we looked for emerging themes during our open coding analysis (Glaser and Strauss, 1967), such as subsidy-dependence, (local) anchor investors, or a mismatch of investment cycles or sizes emerged. The different quotes in the categories were aggregated into themes ${ }^{9}$ by recognizing patterns in the data that describe relationships between the various actors (see Figure 6). For example, the role of anchor investors was mentioned by VC/PE funds and by limited partners alike, who both perceive the importance of an early and considerable involvement as key to a successful fundraising process. Thus, we could verify the involvement of public investors as anchor investors in subsequent interviews.

In our final step, we went beyond a mere presentation of patterns and descriptive comparisons to explain the reasoning behind the categories that were identified. Adopting a comparative case narrative, we organized the different themes within the finance-innovation-policy nexus to demonstrate the different characteristics in the United States and Germany.

We took a number of measures to ensure the robustness of our analysis (Patton, 2002; Moran-Ellis et al., 2006). Construct validity has been achieved through the use of several data sources (archival documents for the interview preparation, notes, and interview transcripts). This allowed us to triangulate the understanding of key concepts to avoid misinterpretation (Patton, 2002). To ensure internal validity (avoiding alternative explanations) we compiled a multi-stakeholder sample (including policy makers and innovators) which includes typical cases across of a large set of technologies. This approach enabled us to add to existing theory (Moran-Ellis et al., 2006). We achieved reliability by conducting the field research with two scholars, developing and refining the semi-structured interview guide for the interviews, recording and transcribing the evidence. Finally, we verified and extended the US-German comparison by holding a workshop with 20 US and European scholars and practitioners active in the cleantech sector.

\section{Findings}

We present our findings in six groups consisting of two types of policy-finance and innovation-that each affect three types of actors-institutional investors, PE/VC, and innovators. For each group we show direct and indirect

9 According to Dutton and Dukerich (1991: 524), themes are "recurrent topics of discussion, action, or both on the part of the actors being studied [...] that captures the central ideas or relationships." We refer to a theme when at least three interview participants coded in different relationships discussed a topic. 


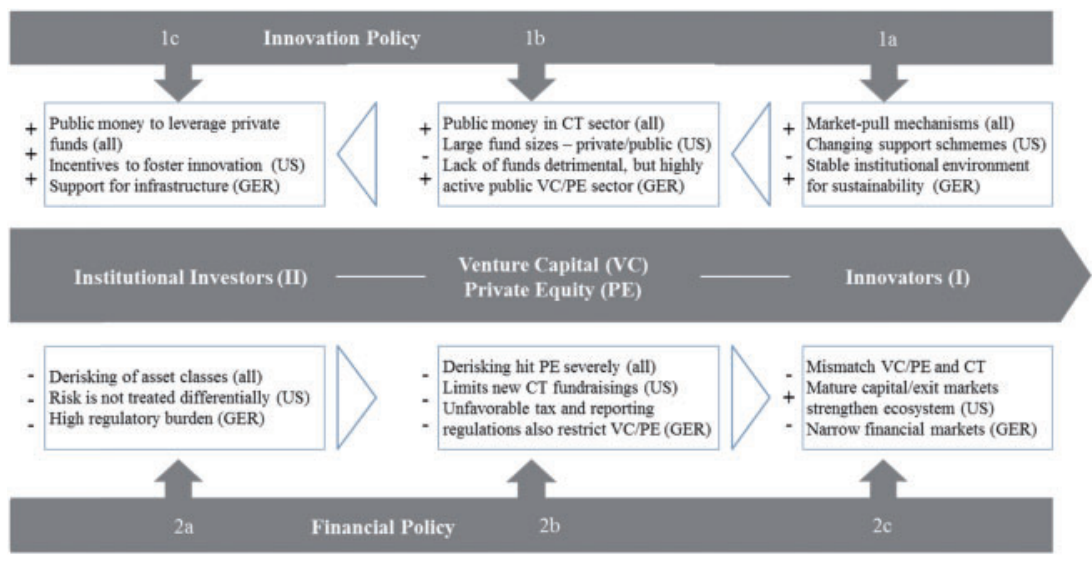

Figure 7. Final model including interactions and mechanisms (based on findings).

effects, which we juxtapose starting with the actors most directly affected by the respective policy. Our main findings are represented as mechanisms in the finance-innovation-policy nexus showing how innovators are affected by policy affecting institutional investors to PE and VC investors (see Figure 7). On the one hand, financial policy targeting institutional investors may cause trickle-down effects via PE and VC investors toward cleantech innovators (which are not directly affected by specific policy measures). On the other hand, we see effects of innovation policy on cleantech, $\mathrm{VC} / \mathrm{PE}$, and institutional investors. Tables A1 and A2 provide additional individual quotes which support the following reasoning.

\subsection{Innovation policy (direct and indirect) effects}

\section{(1a) Innovation policy and cleantech innovators}

Policy makers enact different mechanisms to either push technology or pull demand from the marketplace as a firsttier (direct) effect. On the one hand, technology push throughout the R\&D phases accelerates innovation that can be later picked up by investors. On the other hand, from an investor and innovator perspective market-pull mechanisms like feed-in tariff and cash rebates are seen as more effective for mobilizing private early-stage finance than, for example, straight tax incentives that depend too much on the existence of taxable positive returns. Direct influence or even investments by government authorities might even distort the private sector: "For cleantech, it is a deal-breaker if the business model is reliant on subsidies" (GER10—PE Investor). Sometimes they compete with private market participants and affect their returns, or even crowd-out private investments. However, in early phases government involvement is needed. "The government is trying to make sure we grow the innovation base and provides a source of capital to get products out of the classroom to the market" (USA6-Policy maker).

Additionally, government regulation can build up frameworks to strengthen innovative businesses. In the relation between innovators and investors, long-term and stable regulations are the most important drivers for adoption of technologies and investments in new and innovative companies. In particular, support through long-term and reliable measures fostering the demand side develops certain industries. The solar and wind industries are prime examples of cleantech industries that have flourished due to regulation provided by the German feed-in tariff. However, adverse events such as the cancelation of feed-in tariff rules in Spain have given rise to uncertainty and focus has shifted to business models entirely independent of support mechanisms, according to our interview partners from the investment world.

In the United States, initiatives such as the Department of Energy Loan Guarantee Program (US-DOE LGP) have an ambiguous effect. "The notion was that the government had an important role to play in the creation and the support of a new and important energy sector, much as the government has supported different kinds of energy development over the last hundred and fifty years" (USA19-Policy maker) (cf. Greentech Media, 2014). Investors view the program as problematic and variable. Examples include firms that went bankrupt, resulting in losses for the 
taxpayer, including Solyndra or A123, as well as cases that continue to be successful, such as Tesla. Government initiatives as an example of the entrepreneurial state could also fail as part of the innovation processes.

Compared to Germany, where regulation in the field of cleantech is guided by stronger political will and social commitment toward sustainability, in the United States a fragmented and incoherent regulatory environment and support framework is evident: "the subsidy environment and the understanding of the need for renewable energy is so much lower in the United States versus Germany" (USA12-Policy maker). Yet, this did not necessarily limit the adoption of renewable energy, as witnessed with the additional capacity in wind and solar built in the United States in recent years (IRENA, 2016). Overall, market-driven adoption of technology through competitive prices and efficiency seems to be a suitable way to achieve a sustainable transformation.

\section{(1b) Innovation policy and PE}

To illustrate second-tier effects of innovation policy on the finance-innovation-policy nexus, we describe two policies that indirectly affect PE. First, the US LGP represents an innovation policy that, apart from directly aiming at supporting cleantech innovators, is perceived to consider second-tier effects on the finance equity chain. Despite the criticism of the "government picking winners" encountered by the program, the rationale for it is widely regarded as sound and well formulated. The program drew on the expertise and resources of private investors to screen and select target companies. Thus, whereas the concept of the LGP considered second-tier effects, one reason for some of the more prominent bankruptcies of LGP recipients (Solyndra, A123) lies in the magnitude of the funds dedicated to the program and consequently to individual recipients. Carefully investing more than $\$ 40$ billion in less than 2 years is challenging, particularly if the investments are made in a sector characterized by market and technology uncertainties. Some companies received too much capital (e.g. individual funding round of at least $\$ 100$ million) too early in their corporate life cycle, which resulted in an aggressive growth strategy that made the companies vulnerable to adverse market changes as experienced in 2011.

Second, in contrast to the LGP, which had sufficient capital resources to further support companies that are already VC-backed, VC firms in Germany frequently struggle with scarce capital resources. Bearing in mind the success of the US VC ecosystem, many governments attempt to use VC as a tool within industrial policy. According to data by the European Private Equity and Venture Capital Association in 2011, around 40\% of new funding for VC came from government agencies, compared with 10\% in 2007 (Economist, 2012). Still, public sources of capital alone are not sufficient to create a sustainable investment environment. "[A public initiative] gets to interact with the private sector in a really good way, so they do a lot of early stage funding for us and they create the opportunities for us to then invest in. It's indirect but very important" (USA28-VC). Private local anchor investors are needed to trigger further international investments and to create a sustainable innovation environment to mobilize equity finance. Most of the public programs, for example, Germany's KfW-programs (Kreditanstalt für Wiederaufbau), a stateowned institutional investor, aim at VC investments that have local, stage, and size restrictions, which impose serious limitations on participating VC firms and often result in less than competitive returns as stated by parties involved. Recent experience from institutional investors in the cleantech sector suggests that the returns of the field have not met expectations so far and consequently made fundraising more difficult for cleantech VCs, in particular compared to VCs investing in other industries. The lack of private institutional involvement at this stage leads to less money than demanded by innovators and insufficient fund sizes in general. Consequently, this is seen to result in inadequate investment rounds for cleantech companies.

\section{(1c) Innovation policy and institutional investors}

Finally, measures aimed at innovators indirectly influence institutional investors as a "third-tier" (indirect) effect. Governments are using large-scale investment programs or investment incentives to steer market participants. For instance, the emergence of the cleantech VC industry is closely connected to the Californian "Green Wave" initiative implemented by the pension funds California Public Employees' Retirement System (CalPERS) and California State Teachers Retirement System (CalSTRS). US investors often refer to the leading role of policy makers in mandating investments in certain asset classes or sectors such as cleantech with large volumes of dedicated funds, sometimes even overruling specific risk-return requirements which in turn trickle down toward VC/PE investors. This regulatory push at a time when most of the underlying innovative companies in the CT field were at an early stage and did not 
need later-stage investment rounds created a boom period and led to unfulfilled expectations and poor returns at the fund level.

Similar to the United States, institutional investors in Germany also contributed significant amounts of capital to the cleantech sector. The main difference from a regional point of view pertains to asset allocations that are used in the cleantech sector (see Figure 3). Unlike in the United States, where institutional investors accept VC and PE in technology companies as an asset class, the preferred alternative of German institutional investors seem to be cleantech asset finance investments (mostly solar and wind projects). The technologies deployed here are produced in companies whose scale-up was financed by VC/PE firms. Interestingly, the $\mathrm{KfW}$ continues to make significant investments in cleantech asset finance but ceased its capital commitments to German VC funds in 2012.

\subsection{Financial policy (direct and indirect) effects}

\section{(2a) Financial regulation and institutional investors}

Institutional investors are driven by a balanced risk-return approach to increase their assets. Their work is subject to oversight by regulators and rating agencies, which play a role in limiting and selecting certain preferable asset classes. In the aftermath of the financial crisis, several regulations targeting the banking, insurance, and investment industries were introduced or tightened. These regulations influenced the financial industry at the institutional investor levelBasel III, Solvency II, the Dodd-Frank Act, and the Volcker rule—and are capable of limiting PE fundraising. In the United States, the regulatory changes anticipated by the Dodd-Frank act created the urge for institutional investors to divest riskier asset classes such as PE/VC. In the cleantech sector, this led to a secondary market for institutional investor interests in cleantech funds, which were transferred to (institutional) investors with more risk-taking capabilities at a discount. The possibility of diversification and higher return possibilities as well as the importance for economic development made institutional investors demand a greater allocation in their pension plans or insurance assets in VC/PE.

In addition to actual regulations, uncertainty about anticipated regulatory changes impacts the investment behavior of institutional investors resulting in fewer new investments in certain risky asset classes to anticipate limitations of risk. "When you have economic and regulatory uncertainty people don't want to invest-you have a little bit of a lock up in the market" (GER10-PE Investor). Decreasing allocations to VC by prominent institutional investors provide evidence for this development (Roth, 2012).

\section{(2b) Financial regulation and PE}

Within the finance-innovation-policy nexus, financial regulations directly targeted at institutional investors generate second-tier effects that influence the relationship between institutional investors and PE firms. The undifferentiated approach in which risk is attributed to alternative asset classes within the regulatory framework does not adequately capture actual risk. "A lot of government policy which has rightly been driving risk out of banking doesn't work out favorably in terms of the supply of venture capital" (GER15-VC Investor).

Countries that exhibit a less developed institutional investor base are affected more severely by a loss of anchor investors, which traditionally facilitated further fundraising for PE firms. The loss of state-owned banks in Germany as limited partners for PE created significant challenges due to the lack of local pension funds and endowments that typically fund a large part of the total PE investments. In addition, large parts of institutional investor funds are concentrated in a relatively small number of increasingly large PE firms. Institutional investors need efficient capital allocation with fewer partners and lower transaction costs. This is further accelerated by the preference to allocate funds to the PE firms in the top return quartile. A less diversified institutional investor base also creates challenges for smaller PE funds in attracting attention from fund investors. Traditionally, funds-of-funds have addressed this segment of the market as an additional financial intermediary between institutional investors and PE funds, but they are equally affected by the same regulatory frameworks.

In addition to the second-tier effects, policies targeting VC/PE investors in Germany influence their ability to invest in innovative companies. Particularly in the German market, unfavorable regulations at the fund level impact the size of growth in capital markets. The inability to transfer a loss carry-forward in case of a change in ownership hinders investments in R\&D of young companies and impedes the typical VC investment model in Germany. 


\section{(2c) Financial regulation and cleantech innovators}

Although policy measures targeted at institutional investors can increase or decrease PE funds at the second tier, they ultimately increase or decrease capital availability for innovation at the third-tier level. The impact can be more severe for certain segments of the real economy that are relatively more dependent on external sources of capital, especially asset-heavy sectors such as cleantech. First, PE investors at the early and growth stages of the corporate life cycle frequently syndicate transactions to diversify their holdings and reduce portfolio risk. "Venture capital, more than any other asset class that we look at is a game of syndication, it's a game of participatory risk sharing. Anchor investors have a higher impact of catalyzing current investors and syndicate investors, into investments than a local venture capital fund" (GER13-Institutional Investor). Local capital sources matter as a backbone for the financial value chain: "you can create all the policy framework you like in terms of trying to create a venture capital industry, but unless you're releasing local sources of capital for that, it will never succeed" (GER13-Institutional Investor). The larger a firm's capital requirements, the more important it is to find experienced co-investors to participate in the syndication. Especially in Germany, PE investors are often unable to find partners with sufficient liquid funds to participate in such syndicated deals. In addition, later-stage PE investors increasingly act as exit channels for VC investors. The lack of financial investors to provide an exit route can be severe if, at the same time, other exit routes, such as the public equity market or corporate mergers and acquisitions (M\&A), are not accessible.

In the US cleantech sector, high capital requirements to scale asset-intensive businesses, coupled with the scarcity of syndication partners and long holding periods due to the lack of accessible exit channels lead to a refraining from future VC investment in the cleantech sector. Ultimately, the challenges associated with post-2008 cleantech PE investments in general, and early-stage cleantech VC investments in particular, culminate in the low return profile of many funds dedicated to cleantech.

\section{Discussion}

The research question guiding our inquiry was: How do innovation and financial policy influence the supply and demand of equity finance along the financial value chain? Below we reflect upon our results in the light of our theoretical background.

\subsection{Financing innovation beyond VC/PE-the role of institutional investors}

Extending earlier work, we find that there is a strong role for the financial sector beyond the innovator-VC relationship (Oakey, 2003; Kenney, 2011a; Wonglimpiyarat, 2011; Hargadon and Kenney, 2012; Kenney and Hargadon, 2014). In times of market distortion, policy makers often decide to limit the fallout of capital imbalances. This merits an analysis of the interdependencies between the institutional environment, and the influence of financial policy and innovation policy in the cleantech sector. Given the direct and indirect effects of interactions within the financeinnovation-policy nexus, an active role for financial policy has an impact beyond the direct targets of a specific policy (see Figure 7). The comparison of the financial value chain for cleantech equity investments in Germany and the United States sheds light on these mechanisms and differentiates prior conceptual and empirical work (Kenney, 2011a; Wonglimpiyarat, 2011; Hargadon and Kenney, 2012; Kenney and Hargadon, 2014). These exemplary effects can be transferred to the emergence of other industries, although the density of policies might be lower in less regulated environments.

While policy interventions, such as those in the US LGP, are designed to ease financial constraints on technology firms, in the case of the cleantech sector the minimum capital drawdown was not in line with the technology life cycle. Consequently, some cleantech companies received far more capital than was required at their stage of the technology life, increasing the risks of being financially overstretched and of later financial distress (relation 1a and $1 \mathrm{~b}$ ). Similar effects were observed by Cumming (2011). This can also be seen as some form of government experimentation and an example of the entrepreneurial state (Mazzucato, 2013b). Moreover, innovation policy could target institutional investors to stimulate industry emergence e.g. by mandating investments in specific sectors; whereas in their absence these investments have to come from other sources (relation 1c).

By contrast, as regulation thinned out the European and more specifically German institutional investor base, this led to difficulties in fundraising for VC/PE and thus capital constraints for the overall investment process in regard to syndication and follow on investments (relation $2 \mathrm{a}$ and $2 \mathrm{~b}$ ). Among the factors affecting innovation, institutional 
investors and their relationships with $\mathrm{VC} / \mathrm{PE}$ play a significant role. Without their engagement, financing industry emergence (especially in asset-heavy sectors such as cleantech) becomes extremely challenging (relation 2c).

The analysis reveals that the state (i.e. current level of investment flows between institutional investors and VC/ PE) and structure (i.e. presence of local anchor investors) of underlying equity markets significantly shape sector emergence and growth in a co-evolutionary relationship (see also Avnimelech and Teubal, 2006; Avnimelech et al., 2010). This finding can be generalized across sectors, although the cleantech industry faces higher technological uncertainty and policy risk than most other sectors. With our analysis we extend recent work (Brossard et al., 2013; Revest and Sapio, 2013; Grilli and Murtinu, 2014) by highlighting interdependencies between institutional investors and VC/PE companies that influence the finance environment for cleantech. In addition to tax policy, capital market development, bankruptcy, legislation, securities legislation, and labor market regulation (Lerner, 2002b; Da Rin et al., 2006; Cumming, 2011; Lerner and Tåg, 2013) there is an additional way of supporting VC, namely, targeted policy measures for institutional investors. This could alleviate the recent risk-averse behavior of VC/PE investors (Mazzucato, 2013a).

\subsection{Unintended policy consequences in financing industry emergence-the case of US and German cleantech markets}

This article investigates direct and indirect policy effects that affect actors not targeted by policy makers in the finance--innovation-policy relationship. First, we confirm sector-specific prior research that market-pull policies, for example, feed-in tariffs for renewable energy, attract VC/PE investors into certain industries (Bürer and Wüstenhagen, 2009; Hoppmann et al., 2013; Criscuolo and Menon, 2015). Going beyond the R\&D stage with subsidies or even equity investments, as highlighted by Olmos et al. (2012), does not mobilize professional VC/PE investors or institutional investors. These perceive the policy risk as high and they do not understand the behavior of public sector agents as co-investors (Avnimelech and Teubal, 2006; Avnimelech and Teubal, 2008). Regarding the general VC-Policy linkage we can confirm that exit opportunities, favorable treatment of initial losses in the tax regime and capital market development are leverage points to stimulate VC/PE investments (Da Rin et al., 2006; Lerner and Tåg, 2013). In this regard, institutional investors play a crucial role as they evaluate market opportunities before investing into new funds (relation $1 \mathrm{~b}$ and $1 \mathrm{c}$ ). We confirm the notion that support schemes for VC in specific industries need to take into account mechanisms in equity markets to be effective (Lerner, 2002b; Lerner, 2009; Lerner, 2010; Cumming, 2011).

Second, conflicting aims of innovation and financial policy in the aftermath of the financial crisis represent a casein-point for indirect policy influences. Policy makers targeted excessive risk-taking and unbalanced risk-to-reward ratios to decrease the risk exposure across all parts of the financial industry. While measures to decrease exposure can help to stabilize the state of the financial industry, the impacts of these measures usually lead to a drought of capital for innovators in small- and medium-size enterprises (relation $2 b$ and $2 c$ in Figure 7). Policy makers need to differentiate between "good and bad" risks as suggested by Mazzucato (2013a) to allow risky investments into VC/PE while at the same time limiting speculation in the financial markets.

There are key differences at the second tier between the United States and Germany with respect to the 2008 financial regulations. While the United States exhibit an investor base with the potential to supply PE with substantial funds, there are comparatively fewer investors in Germany with PE experience (McCrone, 2015). This lack of local anchor investors is an obstacle to the fundraising process and can deter outside investors from committing capital, as capital markets are regionally dispersed (Destin, 2012). Therefore, PE faces some challenges in obtaining funding in the United States, and less resilient alternative investment markets in Germany might experience setbacks in their development especially with respect to early-stage financing. VCs in the United States and in Germany, especially in the cleantech and sustainability field, experienced difficulties in raising follow-on funds for their 2006-2008 fund generations (Knowles, 2013).

With our analysis, we add new perspectives on the linkages between financial policy and innovation policy (for an overview about policy blunders see Graham, 2005). Although the financial crisis is an exogenous shock, the systemic question of how financial policy is influencing the conditions for innovation is relevant. The comparison between Germany and the United States revealed that the institutional changes to reduce risk in asset allocations in the financial sector have affected the financing of US cleantech firms less than German firms due to a robust and longstanding base of institutional investors. 
Uncoordinated, individual policies, such as financial market regulation can have powerful ramifications for innovation outcomes that they do not target. In extension of previous literature on policy for early-stage VC/PE finance (Lerner, 2002b; Da Rin et al., 2006; Cumming, 2011; Lerner and Tåg, 2013; Cumming et al., 2016) and policy mixes (Borrás and Edquist, 2013; Magro and Wilson, 2013) we underline the implicit role financial policy plays for innovation. Illustrated by the comparison between the United States and Germany, the economic (and environmental) policy stance regarding cleantech is quite different, while at the same time, the attitude toward financial policy is also different (Hess, 2014). Still, the coupling of objectives of long-term-oriented financial regulation with innovation policy incentives mitigates conflicts. Our empirical findings suggest that scholars should look for more trade-offs involved in decision making of policy makers by identifying other indirect effects (cf. Flanagan et al., 2011; Rogge and Reichardt, 2016).

\section{Conclusions and policy implications}

In this article, we studied the supply and demand of finance along the financial value chain in the cleantech sector, an industry highly influenced by regulation. We include institutional investors as important—and under-studied—actors shaping the conditions for innovation financing by investing into VC/PE firms active in specific subsectors. Consequently, financial regulation affects innovation activities through an indirect effect from institutional investors via VC/PE firms toward innovative cleantech ventures. These findings also hold for less heavily regulated industries, where trade-offs are fewer. Our research highlights that policy makers are advised to look at this process from at least two perspectives: innovation policy and financial policy. The joint consideration allows them to differentiate their policy measures according to the state of the (institutional) investor market in corresponding regions. Anticipating indirect consequences through an advanced understanding of these mechanisms in the equity markets to mobilize private finance is warranted.

Despite all efforts to secure theoretical saturation and holistic consideration in the qualitative data collection, we focused on perceptions of market actors rather than investment flows. Given the qualitative nature of this study, one limitation is based on the context-specific results. These include the sample of only two regions and a specific sector (cleantech). However, keeping generalizability in mind during all steps of the research process, our sampling approach warrants a contribution for regulated environments and with comparatively high capital requirements such as nanotech or biotech. The comparative approach with the United States and Germany in the cleantech field covers a broad range of the market, but we recognize other countries, especially China, would be interesting comparisons. We suggest further research on the complex interactions and interdependencies of the financial markets and other policies complementing our qualitative analysis of perceptions with quantitative data and methods (i.e. investment flows) which could add to our understanding of interdependencies between financial and innovation policy, industry emergence, and financial markets (cf. Avnimelech and Teubal, 2006; Avnimelech et al., 2010; Lerner and Tåg, 2013; Schock et al., 2014).

Our research has implications for policy makers striving to effectively and efficiently foster (cleantech) industry emergence by private finance. We highlight possible conflicting objectives regarding underlying concepts such as the amount of risk taken by different actors involved in financing innovation. This requires a deep understanding of both the national characteristics and agents of the financial markets as well as their impact on firms operating in this (highly regulated) environment.

If the primary goal of policy makers is to stabilize the financial market by decreasing the risk exposure of its constituents, secondary economic-political targets are affected by this decision. In a recessionary environment, secondary targets could be vital to stimulating economic growth, accelerating innovation in certain industries or, in the case of Germany, manage the transition to an alternative energy system. Relating to these secondary goals, enterprises backed by PE firms have been found to generate relatively faster growth, while enterprises backed by VC firms have been found to be relatively more innovative than their peers. Despite these positive economic effects, both PE and VC are deemed risky asset classes and therefore are directly impacted by policies targeted at institutional investors to limit risk in their portfolios.

Where governments view green growth as a priority, they need to address market and system failures, as well as consequences stemming from the interplay of financial and innovation policy. From our qualitative study, we can infer that isolated policy measures might not be conducive to green growth. In fact, our model shows that policy 
makers should try to anticipate consequences for equity markets and develop a clear and transparent strategy for the cleantech sectors and subsectors which integrates the mechanisms linking distinct actors in the financial value chain.

Given the different national institutional settings of the financial sector, it is advisable to keep regulation adjusted to the characteristics and maturity of firms, industries, technologies, and markets. A general support of competition and new entry to mobilize the private finance for innovation and entrepreneurship (such as syndication, networking, etc.; Lerner and Tåg, 2013) financial and innovation policy measures aimed at easing the early- and growth-stage private financing environment for cleantech should be amended. Future policy-oriented research could look into detail which specific policies are conducive to fostering a suitable environment.

\section{Acknowledgements}

The authors are grateful for the time and support of the interviewees. The article benefited from feedback from Martin Kenney, John Zysman, Sanjay Jain, Brett Gilbert, and other participants at the CFI-workshop at the Berkeley Roundtable on the International Economy (BRIE) in May 2012, the Babson College Entrepreneurship Research Conference (BCERC) 2012 in Fort Worth, TX, the RENT 2012 conference in Lyon, France, the DRUID conference 2013 in Barcelona, Spain, and Marko Hekkert and other participants at the workshop on "Institutions and Entrepreneurial Development" in Utrecht, Netherlands, in November 2014 as well as from individual feedback from Paul Nightingale, Mariana Mazzucato, and Carlota Perez during Friedemann Polzin's stay as visiting researcher at SPRU. All remaining errors are the authors'.

\section{Funding}

This work was supported by the Federal Ministry of Education and Research (BMBF), Germany, as part of the research project "Climate Change, Financial Markets and Innovation (CFI)" (grant number 01XX0801A).

\section{References}

111th Congress of the United States of America (2010), Dodd-Frank Wall Street Reform and Consumer Protection Act. https://www. sec.gov/about/laws/wallstreetreform-cpa.pdf 13 July 13, date last accessed].

Arora, S., H. A. Romijn and M. C. J. Caniëls (2014), 'Governed by history: institutional analysis of a contested biofuel innovation system in Tanzania,' Industrial and Corporate Change, 23(2), 573-607.

Aversa, P., S. Furnari and S. Haefliger (2015), 'Business model configurations and performance: a qualitative comparative analysis in Formula One racing, 2005-2013,' Industrial and Corporate Change, 24(3), 655-676.

Avnimelech, G., A. Rosiello and M. Teubal (2010), 'Evolutionary interpretation of venture capital policy in Israel, Germany, UK and Scotland,' Science and Public Policy, 37(2), 101-112.

Avnimelech, G. and M. Teubal (2006), 'Creating venture capital industries that co-evolve with high tech: insights from an extended industry life cycle perspective of the Israeli experience,' Research Policy, 35(10), 1477-1498.

Avnimelech, G. and M. Teubal (2008), 'From direct support of business sector R\&d/innovation to targeting venture capital/private equity: a catching-up innovation and technology policy life cycle perspective,' Economics of Innovation and New Technology, 17(1-2), 153-172.

Bank for International Settlements (2010), International regulatory framework for banks (Basel III). http://www.bis.org/bcbs/basel3. htm 13 July 2014, date last accessed.

Belke, A. H. (2013), Impact of a low interest rate environment-Global liquidity spillovers and the search-for-yield, Bonn. http:// papers.ssrn.com/sol3/papers.cfm?abstract_id=2309963 22 May 2015, date last accessed.

Bewley, T. (2002), 'Interviews as a valid empirical tool in economics,' The Journal of Socio-Economics, 31(4), $343-353$.

Black, B. S. and R. J. Gilson (1998), 'Venture capital and the structure of capital markets: banks versus stock markets1,' Journal of Financial Economics, 47(3), 243-277.

Block, J. and P. Sandner (2009), 'What is the effect of the financial crisis on venture capital financing? Empirical evidence from US Internet start-ups,' Venture Capital: An International Journal of Entrepreneurial Finance, 11(4), 295-309.

Bocken, N. M. P. (2015), 'Sustainable venture capital—catalyst for sustainable start-up success?,' Journal of Cleaner Production, 108(Part A), 647-658.

Borrás, S. and C. Edquist (2013), 'The choice of innovation policy instruments,' Technological Forecasting and Social Change, 80(8), 1513-1522.

Bottazzi, L. and M. Da Rin (2002), 'Venture capital in Europe and the financing of innovative companies,' Economic Policy, 17(34), 229-270. 
Brossard, O., S. Lavigne and M. E. Sakinç (2013), 'Ownership structures and R\&D in Europe: the good institutional investors, the bad and ugly impatient shareholders,' Industrial and Corporate Change, 22(4), 1031-1068.

Bürer, M. J. and R. Wüstenhagen (2009), 'Which renewable energy policy is a venture capitalist's best friend? Empirical evidence from a survey of international cleantech investors,' Energy Policy, 37(12), 4997-5006.

Caprotti, F. (2012), 'The cultural economy of cleantech: environmental discourse and the emergence of a new technology sector,' Transactions of the Institute of British Geographers, 37(3), 370-385.

Colombo, M. G. and L. Grilli (2010), 'On growth drivers of high-tech start-ups: exploring the role of founders' human capital and venture capital,' Journal of Business Venturing, 25(6), 610-626.

Corbin, J. and A. Strauss (1994), 'Grounded theory methodology,' in N. K. Denzin and Y. S. ( Lincolneds), Handbook of Qualitative Research. Sage Publications: Thousand Oaks, pp. 273-285.

Creswell, J. W. (2003), Research Design: Qualitative, Quantitative, and Mixed Method Approaches. Sage Publications: Thousand Oaks, CA.

Criscuolo, C. and C. Menon (2015), 'Environmental policies and risk finance in the green sector: cross-country evidence,' Energy Policy, 83, 38-56.

Cumming, D. (2011), 'Public policy and the creation of active venture capital markets,' Venture Capital, 13(1), 75-94.

Cumming, D. J., I., Henriques and P. Sadorsky (2016), Cleantech Venture Capital Around the World. International Review of Financial Analysis. https://papers.ssrn.com/abstract=2735377 4 December 2016, date last accessed.

Da Rin, M., G. Nicodano and A. Sembenelli (2006), 'Public policy and the creation of active venture capital markets,' Journal of Public Economics, 90(8-9), 1699-1723.

Davila, A., G. Foster and M. Gupta (2003), 'Venture capital financing and the growth of startup firms,' Journal of Business Venturing, 18(6), 689-708.

Dean, T. J. and J. S. McMullen (2007), 'Toward a theory of sustainable entrepreneurship: reducing environmental degradation through entrepreneurial action,' Journal of Business Venturing, 22(1), 50-76.

Demirel, P. and E. Kesidou (2011), 'Stimulating different types of eco-innovation in the UK: government policies and firm motivations,' Ecological Economics, 70(8), 1546-1557.

Demirel, P. and S. Parris (2015), 'Access to finance for innovators in the UK's environmental sector,' Technology Analysis \& Strategic Management, 27(7), 782-808.

Destin, F. (2012), The Great European Venture Capital Crisis. http://freddestin.com/2012/05/the-great-european-venture-capital-cri sis.html 27 May 2015, date last accessed.

Dimov, D., P. M., Holan, and H. de \& ilanov (2012), 'Learning patterns in venture capital investing in new industries,' Industrial and Corporate Change, 21(6), 1389-1426.

Dutton, J. E. and J. M. Dukerich (1991), 'Keeping an eye on the mirror: image and identity in organizational adaptation,' The Academy of Management Journal, 34(3), 517-554.

Economist (2012), Venturecrats. The Economist. http://www.economist.com/blogs/schumpeter/2012/04/european-venture-capital 13 July 2014, date last accessed.

Edquist, C. (2011), 'Design of innovation policy through diagnostic analysis: identification of systemic problems (or failures), Industrial and Corporate Change, 20(6), 1725-1753.

Eisenhardt, K. M. (1989), 'Building theories from case study research,' The Academy of Management Review, 14(4), 532-550.

Ettenhuber, C. (2013), Financing Corporate Growth in the Renewable Energy Industry. PL Acad. Research: Frankfurt am Main.

European Commission (2014), Solvency. http://ec.europa.eu/internal_market/insurance/solvency/index_en.htm 13 July 2014 , date last accessed.

Fitza, M., S. F. Matusik and E. Mosakowski (2009), 'Do VCs matter? The importance of owners on performance variance in start-up firms,' Strategic Management Journal, 30(4), 387-404.

Flanagan, K., E. Uyarra and M. Laranja (2011), 'Reconceptualising the 'policy mix' for innovation,' Research Policy, 40(5), 702-713.

Flyvbjerg, B. (2006), 'Five misunderstandings about case-study research,' Qualitative Inquiry, 12(2), 219-245.

Foxon, T. J. and P. Pearson (2008), 'Overcoming barriers to innovation and diffusion of cleaner technologies: some features of a sustainable innovation policy regime,' Journal of Cleaner Production, 16(1), 148-161.

Francis, J. J, et al. (2010), 'What is an adequate sample size? Operationalising data saturation for theory-based interview studies,' Psychology \& Health, 25(10), 1229-1245.

Garud, R. and P. Karnøe (2003), 'Bricolage versus breakthrough: distributed and embedded agency in technology entrepreneurship,' Research Policy, 32(2), 277-300.

Ghosh, S. and R. Nanda (2010), Venture Capital Investment in the Clean Energy Sector. Social Science Research Network, Rochester, NY: Harvard Business School.

Glaser, B. G. and A. L. Strauss (1967), The Discovery of Grounded Theory: Strategies for Qualitative Research. Transaction Publishers: New Brunswick, NJ. 
Gompers, P. and J. Lerner (2001), 'The venture capital revolution,' The Journal of Economic Perspectives, 15(2), 145-168.

Graham, A. (2005), 'Pressman/Wildavsky and Bardach: implementation in the public sector, past, present and future,' Canadian Public Administration, 48(2), 268-273.

Greentech Media (2014), DOE: The Clean Energy Loan Program Is Already Making a Profit for Taxpayers. http://www.greentechme dia.com/articles/read/The-Clean-Energy-Loan-Program-Is-Already-Making-Money-for-Taxpayers.

Grilli, L. and S. Murtinu (2014), 'New technology-based firms in Europe: market penetration, public venture capital, and timing of investment,' Industrial and Corporate Change, 24, 1109-1148.

Haley, U. C. and D. A. Schuler (2011), 'Government policy and firm strategy in the solar photovoltaic industry,' California Management Review, 54(1), 17-38.

Hargadon, A. B. and M. Kenney (2012), 'Misguided policy? Following venture capital into clean technology,' California Management Review, 54(2), 118-139.

Hess, D. J. (2014), 'Sustainability transitions: a political coalition perspective,' Research Policy, 43(2), 278-283.

Hirsch-Kreinsen, H. (2011), 'Financial market and technological innovation,' Industry \& Innovation, 18(4), 351-368.

Hockerts, K. and R. Wüstenhagen (2010), 'Greening Goliaths versus emerging Davids — Theorizing about the role of incumbents and new entrants in sustainable entrepreneurship,' Journal of Business Venturing, 25(5), 481-492.

Hoppmann, J, et al. (2013), 'The two faces of market support-How deployment policies affect technological exploration and exploitation in the solar photovoltaic industry,' Research Policy, 42(4), 989-1003.

Huang, L. and A. Knight (2015), 'Resources and relationships in entrepreneurship: an exchange theory of the development and effects of the entrepreneur-investor relationship,' Academy of Management Review, 42, 80-102.

Huberman, M. and M. B. Miles (2002), The Qualitative Researcher's Companion. Sage Publications: London.

IRENA (2016), Renewable Capacity Statistics 2016. http://www.irena.org/DocumentDownloads/Publications/IRENA_RE_ Capacity_Statistics_2016.pdf 13 February 2016, date last accessed.

Jain, S. and G. George (2007), 'Technology transfer offices as institutional entrepreneurs: the case of Wisconsin Alumni Research Foundation and human embryonic stem cells,' Industrial and Corporate Change, 16(4), 535-567.

Kenney, M. (2011a), 'How venture capital became a component of the US National System of Innovation,' Industrial and Corporate Change, 20(6), 1677-1723.

Kenney, M. (2011b), 'Venture capital investment in the greentech industries: a provocative essay,' in R. Wüstenhagen \& R. Wuebker (eds), The Handbook of Research on Energy Entrepreneurship. Edward Elgar Publishing: Cheltenham, UK, p. 214.

Kenney, M. and A. Hargadon (2014), 'Venture capital and clean technology,' in M. Huberty and J. Zysman (eds), Can Green Sustain Growth? From the Rhetoric to the Reality of Sustainable Prosperity. Stanford University Press: Stanford.

Kesidou, E. and P. Demirel (2012), 'On the drivers of eco-innovations: empirical evidence from the UK,' Research Policy, 41(5), 862-870.

Keuschnigg, C. and S. B. Nielsen (2003), 'Tax policy, venture capital, and entrepreneurship,' Journal of Public Economics, 87(1), $175-203$.

Knowles, V. (2013), European Cleantech Fundraising 2013-14: Investors Have Their Own Chasm to Cross. http://www.georgieffca pital.com/docs/uploads/0854008001366391730.pdf 24 June 2014, date last accessed.

Kortum, S. and J. Lerner (2000), 'Assessing the contribution of venture capital to innovation,' RAND Journal of Economics, 31(4), 674-692.

Lerner, J. (1998), ‘Angel’ financing and public policy: an overview,' Journal of Banking \& Finance, 22(6-8), 773-783.

Lerner, J. (2002a), 'Boom and bust in the venture capital industry and the impact on innovation,' Federal Reserve Bank of Atlanta Economic Review, 87(4), 25-39.

Lerner, J. (2002b), 'When bureaucrats meet entrepreneurs: the design of effective public venture capital' programmes,' The Economic Journal, 112(477), F73-F84.

Lerner, J. (2009), Boulevard of Broken Dreams: Why Public Efforts to Boost Entrepreneurship and Venture Capital Have Failedand What to Do About It. Princeton University Press: Princeton.

Lerner, J. (2010), 'The future of public efforts to boost entrepreneurship and venture capital,' Small Business Economics, 35(3), 255-264.

Lerner, J., M. Sorensen and P. Strömberg (2011), 'Private equity and long-run investment: the case of innovation,' The Journal of Finance, 66(2), 445-477.

Lerner, J. and J. Tåg (2013), 'Institutions and venture capital,' Industrial and Corporate Change, 22(1), $153-182$.

Li, Y. and S. A. Zahra (2012), 'Formal institutions, culture, and venture capital activity: a cross-country analysis,' Journal of Business Venturing, 27(1), 95-111.

Lüthi, S. and R. Wüstenhagen (2012), 'The price of policy risk-empirical insights from choice experiments with european photovoltaic project developers,' Energy Economics, 34(4), 1001-1011.

Magro, E. and J. R. Wilson (2013), 'Complex innovation policy systems: towards an evaluation mix,' Research Policy, 42(9), 1647-1656. 
Marcus, A., J. A. Aragon-Correa and J. Pinkse (2011), 'Firms, regulatory uncertainty, and the natural environment,' California Management Review, 54(1), 5-16.

Marcus, A., J. Malen and S. Ellis (2013), 'The promise and pitfalls of venture capital as an asset class for clean energy investment research questions for organization and natural,' Environment Scholars. Organization and Environment, 26(1), 31-60.

Mathews, J. A, et al. (2010), 'Mobilizing private finance to drive an energy industrial revolution,' Energy Policy, 38(7), 3263-3265.

Mazzucato, M. (2013a), 'Financing innovation: creative destruction vs. destructive creation,' Industrial and Corporate Change, 22(4), 851-867.

Mazzucato, M. (2013b), The Entrepreneurial State: Debunking Public vs. Private Sector Myths. Anthem Press: London.

McCrone, A. (2015), Global Trends in Renewable Energy Investment 2015. Frankfurt School-UNEP Centre/BNEF: Frankfurt am Main.

Mina, A., H. Lahr and A. Hughes (2013), 'The demand and supply of external finance for innovative firms,' Industrial and Corporate Change, 22(4), 869-901.

Mingo, S. and T. Khanna (2014), 'Industrial policy and the creation of new industries: evidence from Brazil's bioethanol industry,' Industrial and Corporate Change, 23(5), 1229-1260.

Moore, B. and R. Wüstenhagen (2004), 'Innovative and sustainable energy technologies: the role of venture capital,' Business Strategy o the Environment, 13(4), 235-245.

Moran-Ellis, J, et al. (2006), 'Triangulation and integration: processes, claims and implications,' Qualitative Research, 6(1), 45-59.

Mowery, D. C., R. Nelson and B. R. Martin (2010), 'Technology policy and global warming: why new policy models are needed (or why putting new wine in old bottles won't work),' Research Policy, 39(8), 1011-1023.

Mrkajic, B., S. Murtinu and V. G. Scalera (2016), Is Green the New Gold? Venture Capital and Green Entrepreneurship. Social Science Research Network: Rochester, NY. http://papers.ssrn.com/abstract=275765329 September 2016, date last accessed.

Nanda, R., K. Younge and L. Fleming (2014), Innovation and entrepreneurship in renewable energy. NBER. http://www.nber.org/ chapters/c13048 27 March 2015, date last accessed.

Ning, Y., W. Wang and B. Yu (2015), 'The driving forces of venture capital investments,' Small Business Economics, 44(2), 315-344.

Oakey, R. P. (2003), 'Funding innovation and growth in UK new technology-based firms: some observations on contributions from the public and private sectors,' Venture Capital, 5(2), 161-179.

OECD (2013), The Role of Banks, Equity Markets and Institutional Investors in Long-Term Financing for Growth and Development. OECD: Paris.

Olmos, L., S. Ruester and S.-J. Liong (2012), 'On the selection of financing instruments to push the development of new technologies: application to clean energy technologies,' Energy Policy, 43, 252-266.

O'Rourke, A. R. (2009), The Emergence of Cleantech. Yale University. http://gradworks.umi.com/33/61/3361640.html 22 June 2014, date last accessed.

O'Sullivan, M. (2005), 'Finance and innovation,' in J. Fagerberg, D. C. Mowery, and R. R. Nelson (eds), The Oxford Handbook of Innovation. Oxford University Press: Oxford; New York, pp. 240-265.

Patton, M. Q. (2002), Qualitative Research and Evaluation Method. SAGE: Thousand Oaks, CA.

Perez, C. (2002), Technological Revolutions and Financial Capital: The Dynamics of Bubbles and Golden Ages. Edward Elgar Publishing. Cheltenham, UK and Northampton, MA, USA.

Pernick, R. and C. Wilder (2007), The Clean Tech Revolution: The Next Big Growth and Investment Opportunity. Harper Business: New York, NY.

Peters, M. et al., 2012. The impact of technology-push and demand-pull policies on technical change Does the locus of policies matter? Research Policy, 41(8), 1296-1308.

Petkova, A. P, et al. (2014), 'Reputation and decision making under ambiguity: a study of U.S. Venture capital firms' investments in the emerging clean energy sector,' Academy of Management Journal, 57(2), 422-448.

Polzin, F, et al. (2015), 'Public policy influence on renewable energy investments-a panel data study across OECD countries,' Energy Policy, 80, 98-111.

Polzin, F., P. von Flotow and L. Klerkx (2016), 'Addressing barriers to eco-innovation: exploring the finance mobilisation functions of institutional innovation intermediaries,' Technological Forecasting and Social Change, 103, 34-46.

PwC Moneytree (2014), Cleantech MoneyTree Report: Q4 2013. PwC Moneytree. San Jose, CA, USA.

PwC Moneytree (2015), Cleantech MoneyTree Report: Q4 2014. PwC Moneytree. San Jose, CA, USA.

Randjelovic, J., A. R. O'Rourke and R. J. Orsato (2003), 'The emergence of green venture capital,' Business Strategy and the Environment, 12(4), 240-253.

Revest, V. and A. Sapio (2013), 'Does the alternative investment market nurture firm growth? A comparison between listed and private companies,' Industrial and Corporate Change, 22(4), 953-979.

Rogge, K. S. and K. Reichardt (2016), 'Policy mixes for sustainability transitions: an extended concept and framework for analysis,' Research Policy, 45(8), 1620-1635. 
Roth, G. (2012), Pension Giant CalPERS Appears Ready To Abandon Most VCs. PE HUB. http://www.pehub.com/2012/08/pen sion-giant-calpers-appears-ready-to-abandon-most-venture-capital-investing/ 24 June 2014, date last accessed.

Samila, S. and O. Sorenson (2010), 'Venture capital, entrepreneurship, and economic growth,' Review of Economics and Statistics, 93(1), 338-349.

Schneider, C. and R. Veugelers (2010), 'On young highly innovative companies: why they matter and how (not) to policy support them,' Industrial and Corporate Change, 19(4), 969-1007.

Schock, F, et al. (2014), Interdependencies between Technology and Capacity Investments in the Solar Technology Sector. EBS Business School: Oestrich-Winkel. http://papers.ssrn.com/abstract=2501857 22 May 2015, date last accessed.

Schock, F. (2014), 'Private equity financing of technology firms: a literature review,' Alternative Investment Analyst Revew, 3(1), 19-48.

Seawright, J. and J. Gerring (2008), 'Case selection techniques in case study research,' Political Research Quarterly, 61(2), 294-308.

Sine, W. D. and R. J. David (2003), 'Environmental jolts, institutional change, and the creation of entrepreneurial opportunity in the US electric power industry,' Research Policy, 32(2), 185-207.

Stucki, T. (2014), 'Success of start-up firms: the role of financial constraints,' Industrial and Corporate Change, 23(1), $25-64$.

Thomas, D. R. (2006), 'A general inductive approach for analyzing qualitative evaluation data,' American Journal of Evaluation, 27(2), 237-246.

Tsoutsos, T. D. and Y. A. Stamboulis (2005), 'The sustainable diffusion of renewable energy technologies as an example of an innovation-focused policy,' Technovation, 25(7), 753-761.

Veugelers, R. (2012), 'Which policy instruments to induce clean innovating?,' Research Policy, 41(10), 1770-1778.

Weber, K. M. and H. Rohracher (2012), 'Legitimizing research, technology and innovation policies for transformative change: combining insights from innovation systems and multi-level perspective in a comprehensive 'failures' framework,' Research Policy, 41(6), 1037-1047.

Wonglimpiyarat, J. (2011), 'The dynamics of financial innovation system,' The Journal of High Technology Management Research, $22(1), 36-46$.

Wright, M., J. Gilligan and K. Amess (2009), 'The economic impact of private equity: what we know and what we would like to know,' Venture Capital, 11(1), 1-21.

Wright, M. and K. Robbie (1998), 'Venture capital and private equity: a review and synthesis,' Journal of Business Finance \& Accounting, 25(5/6), 521-570.

Wüstenhagen, R. and Bilharz, M., 2006. Green energy market development in Germany: effective public policy and emerging customer demand. Energy Policy, 34, 1681-1696.

Yin, R. K. (2009), Case Study Research: Design and Methods. Sage Publications, Inc.: Thousand Oaks, CA. 
Table A1. Innovation policy (direct and indirect) effects

\begin{tabular}{|c|c|c|c|}
\hline $\begin{array}{l}\text { Innovation policy } \\
\text { Geographical area }\end{array}$ & $\begin{array}{l}\text { Innovators }(\mathrm{I}) \\
\text { Relation } 1 a\end{array}$ & $\begin{array}{c}\mathrm{VC} / \mathrm{PE} \\
\text { Relation } 1 b\end{array}$ & $\begin{array}{l}\text { Institutional Investors (II) } \\
\text { Relations } 1 c\end{array}$ \\
\hline Common & $\begin{array}{l}\text { "The government shouldn't be in the } \\
\text { business of picking winners and losers. } \\
\text { They're not smart enough, they aren't } \\
\text { good VCs, they aren't even equity } \\
\text { firms so that constitutes a problem" } \\
\text { (USA22-Innovator) } \\
\text { "If there is a very capital-intensive busi- } \\
\text { ness in a low-growth industry, and it } \\
\text { relies on subsidies [...], if they go } \\
\text { away, the company disappears." } \\
\text { (GER10-PE Investor) } \\
\text { "Some steady state of affairs in policy } \\
\text { making is a better scenario it seems to } \\
\text { me" (USA19-Policy maker) }\end{array}$ & $\begin{array}{l}\text { "[Clean technology VCs] are } \\
\text { struggling to raise capital be- } \\
\text { cause the returns aren't good" } \\
\text { (USA20-Institutional } \\
\text { Investor) } \\
\text { In my opinion regulatory frame- } \\
\text { works are overrated in their im- } \\
\text { portance for innovative } \\
\text { companies. (GER1-PE } \\
\text { Investor) }\end{array}$ & $\begin{array}{l}\text { "The institutional investors } \\
\text { engaged in the field are hesi- } \\
\text { tant to pursue further invest- } \\
\text { ments until previous } \\
\text { investments are returned and } \\
\text { positive results are realized" } \\
\text { (USA20-Institutional } \\
\text { Investor) }\end{array}$ \\
\hline United States & $\begin{array}{l}\text { "So I think that it is not that the govern- } \\
\text { ment is picking winners and losers per } \\
\text { se; in fact, it is the government essen- } \\
\text { tially offering low-cost financing to } \\
\text { projects the private sector has already } \\
\text { picked in an effort to get a new indus- } \\
\text { try off the ground" (USA19_Policy } \\
\text { maker) } \\
\text { "The political environment isn't very } \\
\text { supportive of our technology. So we } \\
\text { have never developed a business plan } \\
\text { that relies on government support" } \\
\text { (USA3-Innovator) } \\
\text { "in the US there is really no regulatory } \\
\text { inputs [on greenhouse gas emissions] } \\
\text { at all for most of our companies" } \\
\text { (USA18-PE Investor) }\end{array}$ & $\begin{array}{l}\text { "The reason behind [the involve- } \\
\text { ment of private investors] is } \\
\text { that you want the private cap- } \\
\text { ital markets to tell you which } \\
\text { projects they are supporting" } \\
\text { (USA19-Policy maker) }\end{array}$ & $\begin{array}{l}\text { "Back in 2004, the Green Wave } \\
\text { initiative that was started over } \\
\text { at the state capitol came across } \\
\text { to CalPERS and CalSTRS and } \\
{[\ldots] \text { it was decided to put } \$ 200} \\
\text { million into the Cleantech } \\
\text { space across a number of man- } \\
\text { agers" (USA20_-Institutional } \\
\text { Investor) } \\
\text { "So our total exposure [...] is } \\
\text { \$1.5 billion approximately. It's } \\
\text { a very big program, and we } \\
\text { have actually now stopped in- } \\
\text { vesting in clean technology dir- } \\
\text { ectly because we're waiting to } \\
\text { see how things work" } \\
\text { (USA20-Institutional } \\
\text { Investor) }\end{array}$ \\
\hline GER & $\begin{array}{l}\text { "When Germany came up with the feed- } \\
\text { in tariff program is when solar really } \\
\text { took off" (USA11-PE Investor) }\end{array}$ & $\begin{array}{l}\text { "Governments increasingly see } \\
\text { venture capital as a tool of in- } \\
\text { dustrial policy and therefore } \\
\text { [...] around most governments } \\
\text { in Europe, venture capital is a } \\
\text { good thing, same at EU level" } \\
\text { (GER15-VC Investor) } \\
\text { "You can create all the policy } \\
\text { framework you like in terms of } \\
\text { trying to create a venture cap- } \\
\text { ital industry, but unless you're } \\
\text { releasing local sources of cap- } \\
\text { ital for that, it will never suc- } \\
\text { ceed" (GER13-Institutional } \\
\text { Investor) }\end{array}$ & $\begin{array}{l}\text { "Real asset investing does not } \\
\text { really have any upsides, but in- } \\
\text { vestors like it because its risks } \\
\text { resemble fixed income invest- } \\
\text { ing" (GER11-Institutional } \\
\text { Investor) }\end{array}$ \\
\hline
\end{tabular}


Table A2. Financial policy (direct and indirect) effects

\begin{tabular}{lccc}
\hline Financial policy & Institutional Investors (II) & VC/PE & Innovators (I) \\
Geographical area & Relation $2 a$ & Relation $2 b$ & Relation $2 c$
\end{tabular}

Common "The threat of that [regulations to cover capital adequacy], I think, is quite profound so if a pension fund or an insurance company needs to reserve capital differently because it invests in a higher risk asset classes, you are clearly going to do less of it" (GER15-VC Investor)

USA

We don't have a single bank invested in our fund, versus a few years ago. So that's an example of where the institutional investor maybe can't do certain things now, that they could do a few years ago (USA17-PE Investor)

GER

"The ability to release and liberate the pensions to invest in the asset class [VC/PE] is one of the most important policy changes that could be made within our region [Europe]"

(GER13-Institutional Investor)

Public investors like the EIF or the KfW almost have a monopoly. They decide where the money goes in VC. This publicly supported monopoly needs to get abolished (USA 21-Institutional Investor)
"[Fund-of-funds] add an extra fee layer [. . ./and] because they spread the money widely your returns will be fairly average" (GER15-VC Investor)

One rule: No strings attached. If there is a connected regulation to public money to only invest locally or into very specific companies, leading funds will never take it. So only the worse investors take this kind of money and achieve worse returns. (GER10-PE Investor)

"A successful industry, particularly in [the view of] venture capital is about scale and size [...] you have to recreate certain parts of an entire industry that's been built up over 15 years from scratch" (GER13Institutional Investor)

"[Institutional] investors don't really want to get out of bed for a small ticket" (GER13Institutional Investor)

"The cut of the tax loss carry-forward after a bigger investment round or after a sale makes all the investments of a company or indirectly a fund lost.

Therefore an investor who supported some research is systematically disadvantaged against corporates" (GER16-VC

Investor)
"The Cleantech business does not easily match the business ecosystem of venture capital. It is capital intensive, it's highly illiquid and [...] the money is locked up for long periods of time" (USA19-Policy maker-IP)

"If a capital source has internal rate of return as a metric for their investment performance then they are going to have a hard time in Cleantech until the later stages where commercial feasibility has been proven" (USA-Institutional Investor)

"In our typical exit, we sell the company to a larger buyout fund at the end of our holding period" (GER1-PE Investor) 
Table A3. Detailed interview descriptives

\begin{tabular}{|c|c|c|c|c|c|}
\hline Code & Role & Type & Date & \# Interviewers & Contact \\
\hline GER1 & Managing Partner & PE GER & Q4 - 2011 & 2 & Face-to-face \\
\hline GER2 & $\mathrm{CFO}$ & Company GER & Q4 - 2011 & 1 & Face-to-face \\
\hline GER3 & $\mathrm{CEO}$ and Founder & Company GER & Q4 - 2011 & 2 & Face-to-face \\
\hline GER4 & Chairman & PE GER & Q4 - 2011 & 2 & Face-to-face \\
\hline GER5 & Director & Public GER & Q4 - 2011 & 2 & Face-to-face \\
\hline GER6 & Principal & LP GER & Q4 - 2011 & 2 & Phone \\
\hline GER7 & Department Head & Public GER & Q4 - 2011 & 1 & Phone \\
\hline USA1 & Head of Communications & Public USA & Q4 - 2011 & 2 & Face-to-face \\
\hline USA2 & Chief Marketing Officer, Founder & Company USA & Q4 - 2011 & 2 & Face-to-face \\
\hline USA3 & President and CEO & Company USA & Q4 - 2011 & 2 & Face-to-face \\
\hline USA4 & Managing Partner & PE USA & Q4 - 2011 & 2 & Face-to-face \\
\hline USA5 & President and CEO & Company USA & Q4 - 2011 & 2 & Face-to-face \\
\hline USA6 & Program Manager & Public USA & Q4 - 2011 & 2 & Face-to-face \\
\hline USA7 & $\mathrm{CEO}$ & Company USA & Q4 - 2011 & 2 & Face-to-face \\
\hline USA8 & Department Head & Public USA & Q4 - 2011 & 2 & Face-to-face \\
\hline USA9 & $\mathrm{CEO}$ & LP USA & Q4 - 2011 & 2 & Face-to-face \\
\hline USA10 & Managing Partner & VC USA & Q4 - 2011 & 2 & Face-to-face \\
\hline USA11 & Managing Partner & PE USA & Q4 - 2011 & 2 & Face-to-face \\
\hline USA12 & Manager Consulting Services & Public USA & Q4 - 2011 & 2 & Face-to-face \\
\hline USA13 & $\mathrm{CEO}$ & Company USA & Q4 - 2011 & 2 & Face-to-face \\
\hline USA14 & $\mathrm{CEO}$ & Company USA & Q4 - 2011 & 2 & Face-to-face \\
\hline USA15 & President and CEO & Company USA & Q4 - 2011 & 2 & Face-to-face \\
\hline USA16 & Managing Partner & PE USA & Q4 - 2011 & 2 & Face-to-face \\
\hline GER8 & Partner & PE GER & Q1 - 2012 & 1 & Phone \\
\hline GER9 & Investment Manager & PE GER & Q1 - 2012 & 2 & Face-to-face \\
\hline GER10 & Investment Associate & PE GER & Q1 - 2012 & 2 & Face-to-face \\
\hline GER11 & Head of Private Equity & LP GER & Q1 - 2012 & 2 & Face-to-face \\
\hline GER12 & $\mathrm{CFO}$ & Company GER & Q1 - 2012 & 2 & Face-to-face \\
\hline GER13 & Senior Investor & LP GER & Q1 - 2012 & 2 & Face-to-face \\
\hline GER14 & Investment Associate & PE GER & Q1 - 2012 & 2 & Face-to-face \\
\hline GER15 & Partner & VC GER & Q1 - 2012 & 2 & Face-to-face \\
\hline USA17 & Head of Energy Investments & PE USA & Q1 - 2012 & 2 & Phone \\
\hline GER16 & Partner & VC GER & Q1 - 2012 & 3 & Face-to-face \\
\hline GER17 & Partner & VC GER & Q1 - 2012 & 3 & Face-to-face \\
\hline USA18 & ESG Professional & PE USA & Q2 - 2012 & 1 & Phone \\
\hline USA19 & Department Head & Public USA & Q2 - 2012 & 2 & Phone \\
\hline USA20 & Portfolio Manager & LP USA & Q2 - 2012 & 2 & Face-to-face \\
\hline USA21 & President & LP USA & Q2 - 2012 & 2 & Face-to-face \\
\hline USA22 & $\mathrm{CEO}$ & Company USA & Q2 - 2012 & 2 & Phone \\
\hline USA23 & Head of Practice & LP USA & Q2 - 2012 & 2 & Face-to-face \\
\hline USA24 & $\mathrm{CEO}$ & Company USA & Q2 - 2012 & 2 & Face-to-face \\
\hline USA25 & Investment Partner & VC USA & Q2 - 2012 & 2 & Face-to-face \\
\hline USA26 & Senior Project Manager & Public USA & Q2 - 2012 & 1 & Face-to-face \\
\hline USA27 & $\mathrm{CEO}$ & Company USA & Q2 - 2012 & 2 & Phone \\
\hline USA28 & General Partner & VC USA & Q2 - 2012 & 2 & Face-to-face \\
\hline GER18 & Senior Vice President Finance & Company GER & Q2 - 2012 & 2 & Face-to-face \\
\hline USA29 & Vice Presisident Sales & VC USA & Q2 - 2012 & 2 & Face-to-face \\
\hline GER19 & Founder and Chairman & VC GER & Q2 - 2012 & 2 & Face-to-face \\
\hline USA30 & Partner & VC USA & Q3 - 2012 & 2 & Phone \\
\hline GER20 & Head of Venture Capital & LP GER & Q3 - 2012 & 2 & Face-to-face \\
\hline USA31 & Senior Policy Advisor & Public USA & Q3 - 2012 & 2 & Face-to-face \\
\hline USA32 & Principal & VC USA & Q3 - 2012 & 2 & Face-to-face \\
\hline
\end{tabular}


Table A3. Continued

\begin{tabular}{|c|c|c|c|c|c|}
\hline Code & Role & Type & Date & \# Interviewers & Contact \\
\hline USA33 & Investment Manager & VC USA & Q3 - 2012 & 2 & Face-to-face \\
\hline USA34 & Partner & VC USA & Q3 - 2012 & 2 & Face-to-face \\
\hline USA35 & Director & Public USA & Q3 - 2012 & 2 & Face-to-face \\
\hline USA36 & Co-Head & Public USA & Q3 - 2012 & 2 & Face-to-face \\
\hline GER21 & Comissioner & Public GER & Q3 - 2012 & 2 & Face-to-face \\
\hline USA37 & Investment Manager & VC USA & Q3 - 2012 & 2 & Face-to-face \\
\hline USA38 & Princial & VC USA & Q3 - 2012 & 2 & Face-to-face \\
\hline USA39 & $\mathrm{CEO}$ & Company USA & Q3 - 2012 & 2 & Face-to-face \\
\hline USA40 & Founder and Chairman & Company USA & Q3 - 2012 & 2 & Face-to-face \\
\hline USA41 & Investment Manager & VC USA & Q3 - 2012 & 2 & Face-to-face \\
\hline GER22 & Partner & Public GER & Q4 - 2012 & 2 & Phone \\
\hline GER23 & CEO & Company GER & Q4 - 2012 & 2 & Phone \\
\hline
\end{tabular}

Table A4. Sample questionnaire

1. Personal background

- What is your educational/professional background?

- What is your current position in your investment firm? (e.g. Partner, Investment Manager)

- What are your responsibilities in your investment firm?

- How long have you been working for your investment firm?

- How long have you been working in the investment industry?

2. Investment firm background

- Describe the history, structure, and size of your investment partnership/funds.

- Who are your limited partners and according to your knowledge what were the main reasons for their commitment to your fund?

- Did your limited partners influence the selection of the sectors you have invested in?

- In which sectors or subsectors does your firm invest?

- What are the reasons for investing or not investing in the cleantech sector?

3. Investment process

- What is the typical size of your total investment in a company and the typical investment round?

- At the time you first invest in a portfolio company, what is your intended investment horizon or holding period?

- In which stage or stages of the corporate life cycle do you invest? (e.g. start-up, early stage, expansion stage, later stage)

- How many business plans or companies do you review per month, how many of them are considered in more detail and how many are selected for an investment?

- What is the average time you spend on portfolio companies per month and with what tasks are you occupied in this time?

- What are important criteria that you look for in a company that you would like to invest in?

- What are common deal-breakers that you encounter during the investment process?

- Are there any hard (economic or financial) factors that rule out certain investments?

- What is your attitude toward technology risk?

4. Investment environment

- How do you evaluate the current political and regulatory environment for institutional investors and to which degree is it influencing your investment activity?

- How do you evaluate the current political and regulatory environment for the alternative investment/private equity sector and to which degree is it influencing your investment activity?

- How do you evaluate the current political and regulatory investment environment in the renewable energy and "clean" technology sector and to which degree is it influencing your investment activity?

- How do you evaluate the investment opportunities in companies vis-à-vis asset/project finance?

- Which government programs or actions do you consider particularly successful or not successful?

- What are your suggestions for a more prosperous investment environment?

5. Investment challenges

- What are the three most dominant challenges your investment firm is facing in the current environment? 